\title{
THE BIRDS OF MANITOBA
}

MANITOBA AVIAN RESEARCH COMMITTEE, Eds. 2003. Manitoba Naturalists Society, Winnipeg. 504 pages, 80 colour plates, 171 black and white drawings and 62 black and white photographs. $23 \times 31 \mathrm{~cm}$ (91/4 in by $121 / 4$ inches). $\$ 63.95 \mathrm{Can}$.

Impressive, incomparable-any number of superlatives may be used to describe The Birds of Manitoba. A great birding province has just published a great bird book. Thanks to the efforts of the Manitoba Avian Research Committee, the Manitoba Naturalists Society and innumerable volunteers, the book is an excellent production. The superb editing of Peter Taylor, combined with the incredible artistic skills of Rudolf Koes, has produced a volume that is attractive, informative and very readable. This is a large format, hard-cover book amply illustrated with watercolors of birds by Koes and color photographs, as well as black and white photographs of habitats and people, and line drawings, also by Koes, of many of the species mentioned.

The six introductory chapters, illustrated with black and white photographs, provide information on birding hot spots, the history of ornithology in Manitoba, physical geography with respect to bird distribution, ecosystems and habitats for birds, aboriginal cultural beliefs and practices involving birds, and bird conservation.

The second of these introductory chapters, "The History of Ornithology in Canada's Keystone Province," looks back over more than 200 years to the observers, collectors and authors who provide a backdrop for today's professional and amateur birders, from Forster's list in 1772 to Ernest Thompson Seton, the Criddle brothers, Donald Gunn, George Atkinson, Hamilton Lang and Ernest Korman. It also provides background on The Manitoba Naturalists Society and its periodical publications, among them "Chickadee Notes" in the Winnipeg Free Press, a weekly column started by A.G.Lawrence in 1921. Winnipeg's other daily paper, the Winnipeg Tribune, had a similar column "Wild Wings" started by Bertram W. Cartwright in 1928. The Naturalist's Society published a number of lists and journals from the 1880's to the late 1980's, among them Zoolog a joint publication with the Zoological Society of Manitoba which ran from 1968 to 1982 with a name change to Manitoba Nature in 1972. This chapter also has sections on academic ornithology, museum ornithology, the role of Ducks Unlimited, amateur ornithologists, bird artists and the provincial bird emblem, the Great Gray Owl, with Bob Nero's and Herb Copland's involvement with the species.

The fifth introductory chapter, "Aboriginal People and Birds, a Brief Cultural History of Manitoba's First People" delves into aboriginal uses of birds as well as classification systems and beliefs about birds, including the importance of winged creatures, in particular the eagle, bird legends and bird names.

The main focus of the species accounts, as explained in the seventh chapter, is to answer questions about each species such as "Where?", "When?", "How many?" and "How likely?" or "How significant?” Sources of information for the accounts include published sources and museum collections as well as Breeding Bird Surveys, Christmas Bird Counts, the Prairie Nest Record Scheme, the Manitoba Avian Research Committee (MARC) computerized database with over 70,000 observations and MARC's record file (the primary source of information on rare species). 
A total of 43 authors contributed to the species accounts. The individual accounts are in essay form and very readable. They detail migration times, abundance, breeding records, songs and calls, behaviour and field marks. There is a distribution map for each species showing breeding, wintering and migration areas with dots pin-pointing locations of accidental occurrences and extralimital breeding records. The species accounts cover 328 pages; 30 hypothetical, failed introductions and escapee species are listed separately.

Line drawings of 173 species accompany the species accounts. There are also 121 colour portraits of birds and 70 colour photos (rare and uncommon species). Mention must be made of Dennis Fast, who contributed 25 of the colour photos; 35 other photographers provided the rest of the photos. The colour plates are grouped into 5 sections of 16 plates each. Seventeen species are illustrated in both black and white and colour, 47 species (primarily accidentals) have no illustration. As a challenge to some readers, some of the black and white drawings are at the top or the bottom or in part of the adjoining species accounts. These drawings are unlabeled, but the species are identified in an index of black and white drawings near the end of the book.

Occasional bits of humour are included in some accounts. For example: the giant subspecies of Canada Goose, almost extinct at one time "Has evolved from a hunter's myth to a golfer's despair" (p.99), and the Yellow-headed Blackbird: "To gain some idea of the strange chorus that emanates from a breeding colony, imagine a flock of birds taking their first bagpipe lesson" (p.377).

There are five appendices. Appendix A, "Details of Rare Bird Records," is a table of dates, locations, numbers, references and MARC's assessment of status (accepted, unconfirmed or hypothetical) for the 49 rare species (those with 15 records or fewer) and one generic group "Unidentified Ibis." About half of the rare species are illustrated in color photographs grouped on 16 pages of plates toward the end of the book.

Appendix B. "Breeding Bird Surveys," includes a text summary, map and tables of information on the 31 Breeding Bird Survey routes surveyed for 10 years or more between 1967 and 1999 (plus the Beulah and Churchill routes for their inherent interest). Appendix C, "Christmas Bird Counts," similarly provides a text summary, map and tables of data on certain counts-the 20 that have been run at least seven times between 1960 and 1999.

Appendix D lists the scientific names for all organisms other than birds and invertebrates that are mentioned in the text, and Appendix $\mathrm{E}$ is a gazetteer providing the latitude and longitude of the localities mentioned in the book. A detailed bibliography, an index to birds mentioned in the text and a checklist of Manitoba birds complete the book.

The four colour end plates show the Bird Conservation Regions of North America, the Bird Conservation Regions of Manitoba, a topographical map of Manitoba and the major parks and wildlife management areas in the province. The front and back covers and spine show six species of birds in colour, duplicates of Rudolf Koes' portraits that appear in the text and they add a visual appeal to the book.

Shortcomings are few in number, and minor, but none-the-less need comment. The reviewer has a penchant for indices, summaries and totals. While the bird species and other organisms are indexed, a general index would simplify searching for information in the introductory section. The Breeding Bird Survey and Christmas Bird Count summaries are very readable, but totals and listing of all routes would be meaningfulif not in this volume then for future researchers. Banding activities are mentioned only in species accounts. Again, a summary with totals would add to the content of the book. 
A map showing the location of all the localities mentioned in the species accounts would be a help to the reader. Labeling of the colour plates is a bit confusing until you realize that the bird at the top of each plate is listed last in the caption.

These are minor faults and they do not reflect on the overall quality of the book.
Readable, enjoyable, a source of pride for the participants, The Birds of Manitoba is informative not only for Manitoba birders but also for all birders in Western Canada and the northern United States.

Reviewed by William Anaka, 301-57 Russell Drive, Yorkton SK S3N 4B6

\title{
EIGHTEENTH-CENTURY NATURALISTS OF HUDSON BAY
}

\author{
STUART HOUSTON, TIM BALL and MARY HOUSTON. 2003. McGill-Queen's \\ University Press, Montreal and Kingston. ISBN 0-7735-2285-9 Hard cover. \$49.95 Can.
}

This book reflects the long standing natural history (especially ornithological) interests of Stuart and Mary Houston, as well as the climatological scholarship of Tim Ball. In some ways this is a curious compendium, a tome that, appropriately enough, is peopled by "curious men" - an 18th century term applied to those individuals who were curious about the natural world. These "curious men" were the forerunners of the scientists whose disciplines became formalized in the 19th century.

The book begins with a series of eight colour plates of avian water colours by George Edwards, whose work complemented and supported the taxonomic efforts of Carolus von Linnaeus. This very attractive opening section is followed by an introductory essay which sets out the rationale for this volume: “... to make amends for past neglect ..." of "... the outstanding achievements of a small group of early weather observers and natural-history collectors around Hudson Bay ..." (p. 3). This introductory chapter then proceeds to a succinct overview of the Hudson's Bay Company (HBC), the latter's predominantly Orcadian workforce, the posts around the Bay, the aboriginal peoples of the region, and the nature of the times. With regard to the latter, it is noted that the HBC's trade began during the Little Ice Age, "just prior to the coldest decade, the 1680s" (p. 11). It is becoming more and more apparent to historians, geographers and anthropologists that climatic conditions at this time must be carefully considered for the impact they may have had on aboriginal lifeways and European mercantile adventures. The introduction also provides a discussion of the blossoming of natural history studies in western Europe (especially Britain) in the last half of the 18th century: “... in all of North America, Hudson Bay was second only to South Carolina as a source of records and data for the revolutionary scientific endeavour led by a Swede, Carolus von Linnaeus, ..." (p. 3).

Chapter 1, "The European Connection", sets out in considerable detail, the scholarly context which received the natural history observations and materials from Hudson Bay. In particular, the scholarly activities of Sir Hans Sloane, George Edwards, Carolus von Linnaeus, Johann Reinhold Forster, Thomas Pennant, John Latham, Rev. Dr John Walker, and Samuel Wegg are summarized. The eight chapters that follow each outline the natural history activities and contributions of an individual $\mathrm{HBC}$ employee on Hudson Bay: 
Alexander Light, James Isham, Humphrey Marten, Andrew Graham, Thomas Hutchins, Moses Norton, Samuel Hearne and Peter Fidler. Each of these men was involved in collecting various plant specimens, as well as study skins of birds and mammals. These collections were made as a result of formal requests to the board of the HBC by the Royal Society. Of these collectors on Hudson Bay, only Dr. Hutchins was formally trained, although both Isham and Graham wrote substantive treatises on the natural history of the York Factory and Ft. Albany regions. The observations of Samuel Hearne are singled out for particular praise.

Chapter 10, "Natural History", details the new faunal and floral species that were officially recognized as a result of the collecting efforts of the men on Hudson Bay. The meaning of the adjective "Hudsonian" is discussed, as well as the motivations of the collectors and the difficulties of preserving study specimens. Very useful is a consideration of a number of previous errors and omissions relating to natural history observations on Hudson Bay.

Chapter 11 , presumably mainly from the pen of Dr. Ball, is entitled "Climatology". This fascinating essay recounts the nature of the meteorological observations kept at the posts on Hudson Bay, particularly temperature and daily weather observations. Astonishingly: “... no other region of the world has such an extensive and detailed record of climate and environment over such a prolonged period" (p. 117). In particular, Ball and others have developed techniques by which to extract and systematize these observations in order to determine climatic changes since the late 1600 s in this huge section of interior North America. Significantly, the long term observations of resident fur traders, and especially of aboriginal elders in the 18th and 19th centuries are identified as of considerable importance. Notably, the aboriginal peoples were well aware of the fact that the tree line had formerly been farther north (p. 134).

The final Chapter, 12, "In Striking Contrast: Charles Town," is an overview of the significance of this city (present day Charleston, South Carolina), culturally and industrially, in the 18th century. The background to the natural history collections made by educated residents of this city is discussed.

A series of seven appendices completes this treatise. Oddly enough, most of these have titles that differ from those listed in the table of contents. The first appendix is a table listing the ships that sailed annually to Hudson Bay from 1716 through to 1892 , along with their dates of arrival and departure, as well as notable events or misadventures - such as the inability to even get into Hudson Bay in the summer of 1816 (the year there was no summer). Appendix 2 is a short account by Deidre Simmons of the history of the storage and archiving of the HBC papers, through several buildings in London, followed by their transfer to Winnipeg in 1974 and their eventual incorporation into the Provincial Archives of Manitoba. Next there is a thoughtful piece of detective work by Stuart and Mary Houston regarding the authorship of ten pieces of writing by Andrew Graham and Thomas Hutchins. Some of the documents are by one or the other, but there are also cases of collaboration-and even what we would now see as plagiarism-although this activity was differently regarded in the 18 th century.

Stuart Houston presents a very useful essay on the ten-year population cycles of the snowshoe hare, lynx, and several other mammals and birds. He notes the various biologists who have employed the HBC data to elucidate this 10 year cycle. Clearly, scientific knowledge of this cycle would have been reached much more slowly without the fur trade records of the HBC. Particularly fascinating is the fifth appendix, "How the HBC Swan Quill and Swan Skin Trade 
Almost Extirpated the Trumpeter Swan". The trade in quills (for pens) and skins (for items of clothing, and for ladies powder puffs) accelerated in the early 1800 s, reaching a peak in 1834 when 7,918 skins were traded. Nor surprisingly, by 1935 there were only 69 trumpeter swans known south of Alaska. This overview is useful in placing local HBC activities into a larger context. For instance this writer has been involved in reviewing the Ft. Carlton post journals, and this essay makes explicable the several references to trading swan skins and swan quills - with, incidentally, prominent mention of hunting swans at Duck Lake, $18 \mathrm{~km}$ east of Ft. Carlton.

The final appendix, "Cree Names for Natural History Species", was prepared by Stuart and Mary Houston, with the assistance of Arok Wolvengrey and Jean Okimasis, specialists in Cree linguistics with the Saskatchewan Indian Federated College, their contribution is invaluable since it provides the contemporary standard orthography for most of the Cree vocabulary items. This appendix is substantial, running to 48 pages. It consists of the Cree terms in standard orthography - i.e. okiskimanasiw 'kingfisher' - followed by the various renderings of that term as recorded by fur traders and anthropologists. This large number of Cree terms for birds, mammals, amphibians, fishes and plants reflects the fact that the largest aboriginal group with whom the HBC traded were Crees and that Crees were in a position of considerable power, a relationship that was unusual from a global perspective. They provided the furs but, very importantly, they also had the skills to live well in the boreal forest as well as the geographical knowledge that allowed long distance travels on the waterways. In this situation, the traders had to acquire a working knowledge of the Cree language. As a result, they learned the names of many plant and animal species. Very importantly, this also enabled them to converse with regional residents about animal behaviour, weather, and climatic fluctuations.

With regard to the appendices, it is not clear just why some of these could not have been chapters in the main body of the text. As well, the book ends with the chapter on Charles Town. While interesting, and necessary to place the Hudson Bay natural history information in perspective, this does not serve well as a summary chapter. No matter, this book is a wonderful piece of scholarship. It reflects the long experience and research of the senior "curious people" who have prepared it. This treatise will become a permanent reference source for scholars involved in biological, ecological, historical and anthropological research in interior Canada.

Reviewed by David Meyer, Department of Archaeology, 55 Campus Drive, University of Saskatchewan, Saskatoon, S7N 5B1

\section{WHOSE BIRD? COMMON BIRD NAMES AND THE PEOPLE THEY COMMEMORATE}

BO BEOLENS and MICHAEL WATKINS. 2003. Foreword by Ben Schott. Yale University Press, New Haven and London. 400 pp., 154 b/w photographs. Soft cover. ISBN 0-30010359-X.

This is a book for anyone who finds birds interesting. It will almost certainly provide intriguing, even new, information for the most dedicated ornithologist and will amaze and delight the novice. The authors hope readers' curiosity will be aroused and that their work will satisfy the urge to know. Both authors are birdsmart. Beolens, well known as "the fat birder," runs one of the most widely used websites on the Internet 
$<w w w$. fatbirder.com $>$ and Watkins has traveled around the globe in pursuit of sightings.

According to Schott's Foreword, Whose Bird? "celebrates two eternal forces of human nature: the unquenchable thirst for knowledge, and the insatiable hunger for fame." Its cast of characters includes "heroic adventurers, library-bound boffins, aristocratic patrons, mysterious lovers, fortunate schoolboys, respectable scientists, and caddish charlatans...each of whom has achieved immortality through having a bird named after them." The list of "eponymous" bird names (bird names which include a person) totals 2368, honouring 1124 individual people.

Whose Bird? also provides a heaping measure of good-humoured and amusing reading. In short, it's fun to peruse-a surprising discovery in view of its encyclopedic format; hazy, often blurred photos and myriad dates and numbersusually dry reading at best. Where else might you find out that Cora's Sheartail was named for a mythological Inca princess of the sun, or that Maria Emilie Snethlage was the first woman scientist to work in Amazonia, or that no fewer than three of those individuals featured were killed by elephants.

The introduction chronicles the book's long and somewhat tortuous, though joyous, birthing. It also tells the reader how to use the book-including a lengthy look at some of the devices used by the authors in accounting for changes in bird names across the centuries, differing conventions used by early ornithologists, creeping errors over time and problems arising out of inconsistencies and idiosyncrasies in nomenclature. Their detailed "instructions" are difficult to follow unless you look at various entries as you read them.

In a chapter titled "How to get a bird named after you," the authors say the best way is to discover a new bird-in the field, in a dusty museum collection, or in the fossil record. This would have been decidedly easier some centuries ago, when many species were "new" and present chances of gaining immortality this way are few. In future, say the authors, we'll doubtless see new naming opportunities through studies of DNA, and, perhaps, the privilege of naming may result from auctions, to be won by the highest bidder.

Amusing "text boxes" scattered throughout treat a variety of commonalities among the over 1000 people for whom birds have been named: females, aristocrats, botanists, charlatans and cheats (who invented, lied and stole to make their names known), X to XXIV (the numbers of birds named for particular individuals, e.g., John Gould - 24; Charles Darwin - 21; P. L. Sclater - 19); watery graves (those who were drowned or shipwrecked); RTAs (road traffic accidents); lost at sea, and many others. Eleven species are named simply for "Mrs" someone.

Individual entries range in length from a couple of phrases to well more than a pagethe latter describing Richard Meinertzhagen, a most remarkable collector who was eventually accused of thievery and fraud and branded a kleptomaniac.

A bibliography and an appendix of species listed alphabetically by scientific name complete the volume.

If you've ever been curious about the human source of an eponymous bird name, this book may give you all the answers you want. It's not the kind of tome to be read in one sitting, but rather to keep handy for questions.

Reviewed by Mary Gilliland, 902 University Drive, Saskatoon SK S7N 0K1 E-mail: birdwoman@shaw.ca 